\title{
THE POSITION OF WOMEN IN THE CHRISTIAN CHURCH.
}

Reverend E. W. Stone, Newnan, Ga.

The status of women in the church is just now a subject of considerable interest to Southern Baptists. Shall they be allowed to speak or otherwise publicly participate in religious assemblies of mixed audiences? A sharp division of sentiment exists on this question, due solely to a difference in understanding the intent and scope of certain words of the Apostle Paul. Writing to the Corinthians he says, "Let the women keep silence in the church; for it is not permitted them to speak...... And if they would learn anything let them ask their own husbands at home; for it is a shame for women to speak in the church." (1 Cor. 14:34-35.) Of his own practice in the matter he writes in a similar strain to Timothy: "I permit not a woman to teach, nor to have dominion over a man, but to be in quietness." (1 Tim. 2:12.)

A great many interpreters hold that in these words the Apostle has settled the question once and for all. They unhesitatingly and emphatically assert his command and practice to be the word and will of God, and therefore, normative for all conditions, and authoritative for all times and people; that they must be regarded as constituting an official and conclusive rule of faith and practice, which determines the position of women in the church, and which was meant to cover the whole future of its history.

Another group of scholars insist that these statements of the Apostle were meant to be local, national, and transitory. They hold as firmly to the authority of the Scriptures as the first class of interpreters, but differ from them in holding that the command to the Corinthians was meant only for a particular time and place, and to be enforced for a particular reason. They do not consider that 
it was ever meant to be a general utterance of Christianity, much less its final word on the subject. His practice as stated to Timothy must be understood in the light of his great principle of conduct in being made all things to all men, and not as setting forth either his ideal for, or his invariable attitude towards women in the church. In the light of the whole of the New Testament teachings of the real purpose of Christianity, and of the providence of God, which of these conflicting views must be regarded as tenable?

It is only fair to say, at the beginning, that the first class of interpreters concede the point at issue to the extent of materially limiting the sphere in which women are to keep silence in the church for the present day at least. They admit that a woman may very properly teach a male or mixed adult class in a Sunday School or other Christian institution, sing to a mixed assembly, and run no serious risk of eternal condemnation by obtaining her information from other sources than an ignorant, or godless, or even a devout husband, provided she has one. What they do contend for is that Paul's teaching prohibits women, under any and every circumstance, from speaking to a Sunday morning congregation in the church, or to a Southern Baptist Convention, or from taking part in a Wednesday night prayer or conference meeting. One can hardly refrain from a smile at this disingenuous attempt to reconcile long established and universally prevailing customs with a rigidly literal interpretation of Paul's command. Surely if this command denies to women of all time and conditions the right of public teaching or other religious activity in one line of church work, it does in all. It cannot be against the word of God for them to teach men at eleven o'clock Sunday, and in accord with it for them to do the same thing in the same place an hour earlier.

But what of the contention of the second class of scholars who insist that the command is of a temporary char- 
acter? That there is a temporal element in the New Testament-commands, exhortations, precepts meant to be local and transient in their applications, will hardly be questioned. For example, Paul writes the Corinthians in the same epistle, that when their women pray and prophesy in public they must do it with veiled faces. (1 Cor. $11: 5,6$.) But the most rigid literalist does not demand that all women who come into the church today for worship must be veiled. If he does not know that the unveiled woman found on the streets, or in public places in Corinth in Paul's time, was looked upon as a courtesan, he does concede enough to modern customs and conventions not to raise a howl when the women of Atlanta or Louisville in the twentieth century disregard the Apostle's injunction to their sisters in the Paris of the first century. No one will deny the desirability of close affection and intimate fellowship between Christians, but there are very few who would not doubt the advisability today of literally following the command, "Salute one another with a holy kiss." The grace of humility is to be devoutly wished for, and the Master's inculcation of it never to be forgotten, but with few exceptions Christians do not feel called upon to manifest it, under modern conditions, by washing one another's feet. The exhortations and counsels of the eighth and tenth chapters

First Corinthians, concerning the eating of meats, have in them a principle of brotherly consideration that is always worthy of the highest emulation, but the literal interpretation of and obedience to some of them today would be pointless, for the circumstances which called them forth no longer exist. And may it not be within the range of possible that the command of the Apostle to this same Corinthian church, concerning the silence of women in religious assemblies, should be placed in the category of these and other similar portions of the New Testament, which are beyond all question, local and transient in their application? 
Probably the most convincing answer to this question will be found in considering the command from a slightly different point of view. Does it, together with the Apostle's practice as declared to Timothy, correctly represent the spirit and teachings of the New Testament as to the position of women in the first Christian churches? In the Gospels women occupy a prominent and honorable position. No limitations, whatever, are placed on their privileges or rights. Mary and Martha, of Bethany, are counted among the closest friends of Christ. He accepts the penitent love of a woman and sets her on a pedestal above the self-righteous Pharisee. To the unknown Samaritan woman Jesus revealed the profound truth: "God is a spirit, and they that worship him must worship him in spirit and truth." And with the fire of this great revelation burning in her soul, she became something of an evangelist herself: "Come see a man who told me all things that ever I did; can this be the Christ?" In all of His journeyings up and down the land, women accompanied Him everywhere, and did Him and His cause invaluable service. It was to Mary Magdalene that the risen Lord first appeared. And it was to her "and the other Mary" that the angel of the Resurrection gave the commission, "Go quickly, and tell his disciples that he is risen from the dead."

In none of the addresses or letters of any of the Apostles to Jewish Christians is there any word or command against the public activity of women in religious work, or that puts any limitation on their sphere of service. Had there been such a word or command given by them, it would have been in condemnation of long established Jewish practices. The Old Testament abounds in references to prophetesses. Their position was recognized, and their influenee acknowledged. As late as Christ's day there were not wanting those who filled this office. When the infant Jesus was brought to the temple, He was received by Anna, the aged prophetess, "Who departed not 
from the temple, worshipping with fastings and supplications night and day." Peter explains the mystery of Pentecost as a fulfillment of Joel's prophecy: "It shall come to pass in the last days, saith God, I will pour out of my spirit upon all flesh : and your sons and your daughters shall prophesy, And on my scrvants, and on my handmaids, I will pour out in those days of my spirit; and they shall prophesy." To prophesy is first to foretell, then to instruct, to teach. So Peter's explanation amounts to this, that the Holy Spirit was given to women on the day of Pentecost that they should teach and instruct. Indeed, this is just what he unequivocally declares. The daughters of Phillip were prophetesses; and if this means anything at all, it certainly means that those young women were possessed of gifts, which were exercised for the benefit of the church. Phobe, a deaconess, was commended to the entire church at Rome. Euodias and Syntyche labored with Paul in the gospel. Priscilla was a theological tutor of Apollos. And Paul lays down, in Galatians $3: 28$, the universal truth that in Christ Jesus "there is neither male nor female" as a great basal Christian doctrine. In Him all distinctions cease. There is no sex or gender for faith, love, service, learning, eloquence, teaching. They belong to all who possess them.

It is only in Greek churches, or in churches where Greek influence predominates, that limitations are placed by the Apostle on the rights and privileges of women. When he wrote his first letter to Timothy, who at the time was probably laboring among the churches in Asia Minor, he was aware that there were Jewish Christians in those churches, but he also knew that Greek customs and opinions generally prevailed in those churches. But why does he command silence for the women in Greek churches? Undoubtedly because of the ideas of womanhood entertained in Greek communities. Here she was expected to remain at home in seclusion, and to be the absolute slave of her husband. She was not to be known beyond the 
limited sphere of her family. She was not expected to meet her own husband at the door on his return home, lest she be seen of other men. She could not go on the streets, nor appear anywhere in public, unless veiled. No woman with an unveiled head could sit in a public place and retain her reputation for virtue. A woman could not learn poetry, art, music, philosophy without being stamped in the eyes of all men as a courtesan. A virtuous woman was an ignorant domestic drudge. Corinth was famous, at this time, for its courtesans. Its licentiousness was notorious. It actually passed into the Greek vocabulary. To "Corinthianize" was to play the wanton. The reputation of the city became a theme for Latin poets. The crass indifference of the Corinthian Church, (1 Cor. 5 ), to a heinous form of immorality, of which some of its members were guilty, is a striking commentary, both to its own utter self-absorption, and to the moral ideals of the community at large.

Such being the position of women at Corinth, and more or less generally so in all Grecian communities, what would have been the effect if in the Christian assemblies a woman with uncovered head had risen to speak or pray? The Greek would have said: "The church is a house of orgies. Christianity teaches our wives that they must forsake their virtues and imitate the courtesan." So to prevent this Paul said to the Greek Christians: "You must not violate the customs of your country; you must not discredit the religion of the Lord Jesus Christ by doing that which every man who sees it will interpret in but one way. Let your women keep silence in the church. Abstain from every appearance of evil." And under the circumstances, his command was undoubtedly the word of God, for the whole tenor of the New Testament is to enjoin upon men the proper performance of the duties of the station to which they belong. Hence every soul is commanded to be in subjection to the powers that be, for to resist them is to withstand the law of God. All men 
are to "honor the king"'; slaves are to obey their masters; and wives are to be in subjection to their husbands. But no literalist would insist that these commands are obligatory when the "powers that be" degenerate into tyrants that set themselves up in place of God, when democracies have supplanted monarchies, when fetters have been stricken from slaves, and when wives have been elevated to partnership with their husbands. In all these, as well as in other situations that could be instanced, the station and the proper duties belonging thereto are influenced by the course of events. Naturally then the question arises, Is there any good reason for making an exception in the single case of a command given for women in a degraded station? When the station changes, does the command still apply? Is this the one instance in which an exception is to be made to the whole tenor and spirit of the New Testament in dealing with local and temporary situations? Even if we were disposed to do it, we are confronted with the unequivocal facts that women of the same time, in other communities and under different circumstances, by the special anointing of the Holy Spirit and by the encouragement of the same Paul, did the very thing he enjoined the women living in the degraded station not to do.

There is another consideration, not without its weight, in determining the character of Paul's command for the women of the Grecian communities. Christianity in its very nature is a revolutionary force. Its foes once said: "These that have turned the world upside down have come hither.', It incites revolutions. It inverts existing arrangements. It is troublesome leaven disturbing the stagnant lump of conformity. Pope's optimistic line, "Whatever is, is right," is not the standpoint of the religion of Jesus Christ. But it does not undertake to accomplish revolutions by determining forms of government, or by fixing social customs, except such as involve moral issues, or by marking out the whole future economy 
of the race. It would be against its very genius to force its aims by external methods. Its supreme purpose was, and must ever be, a new creation in Christ Jesus-a noble manhood fashioned after the likeness of the Perfect Man. To this new and Christ-filled manhood was left the utmost liberty in respect to external things. It was left free to determine all economies in the state and church and school and family, according to its light and experience from age to age. Was it not of this Jesus was speaking when He said: "I have many things to say unto you, but ye cannot bear them now"? Is it not His promise that the Spirit should guide this manhood into all truth: that "He shall take of mine, and shall show it unto you"? Surely it falls under the condemnation of that precept "the letter killeth, the spirit giveth life," and is nothing short of travesty on the New Testament, for one to proceed on the hypothesis that Christ and His Apostles gave definite laws for the regulation of the customs and forms of this new creation-this redeemed manhood-at every possible stage of its future development.

Take as an illustration human slavery which flourished everywhere in the New Testament period. Nowhere does Christ directly attack this institution that is unendurable to the Christian conscience of the present day. His method of dealing with it was by teaching the preciousness of the human soul. Nowhere does Paul urge its abolition. On the contrary he bade Christian slaves be obedient to their masters. But when he wrote "In Christ Jesus is neither bond nor free," he penned the emancipation charter for slaves of all times. He sent back to Philemon his runaway slave, Onesimos, but on what terms? No longer as a slave, but as a "brother beloved." On such terms slavery could not exist. The New Testament principle carried human liberty at its heart. The institution of slavery could not thrive in the atmosphere created by its teachings. 
And what was true of this institution was true also of the whole of the social and civil orders in existence at the time of the entrance of Christianity into the world. Particularly noticeable has been the revolutionary influence of the teachings of Christ and His Apostles on the status of woman in society in general. She has been exalted to equality with man. Every avenue for self-development has been opened to her. No door of opportunity is shut against her. In all Christian civilization there is hardly to be found a political or social law restricting her upward progress. It is only when we come into the religious realm that there are to be found those who strenuously insist on limiting her privileges and duties. These contend that no revolution in her social or mental condition could materially affect her position in the church. But are we to suppose that the religious nature of woman is the only part of her that Christianity cannot effect a revolution in? Or if it does effect a revolution there, is it merely a subjective one, without power at any time to create new conditions for its more perfect expression? Is this the only revolution of which we have knowledge that is denied the right of determining for itself what forms and customs shall obtain? Are we to find here the one exception to the whole history of the revolutions accomplished by the religion of Jesus Christ? In spite of all that Christianity has done for woman, is her position in the Christian church to remain what it was two thousand years ago under the most degrading ideals prevailing in Grecian communities? Can any unbiased man believe that Paul ever suspected there would be those, these two millenniums later and under wholly different conditions, who would be insisting that in giving his command to the Corinthians he was, by inspiration or otherwise, laying down a permanent principle for all possible future conditions in the church.

Suppose, in view of what Christianity has done for woman, Paul had been announcing such a principle to be 
of universal application, what would be the result of a rigid conformity to a literal interpretation of it? The shadow on the dial would have to be set back. The tide of hundreds of years of Christian civilization would be turned again. Higher education for virtuous women would be given up and the doors of all colleges would be closed against them. They would cease to write books, and the very notes of song would die from their lips. They would be forced out of school rooms, and eliminated from every moral and social movement for the betterment of the race. They would be driven to forsake myriads of tender ministries for which they have proven themselves so eminently fitted. They would be imprisoned in their homes, and every ray of elevating influence they might hope to shed would be lost behind a cloud of veiling. Should the tide of civilization thus be turned back, its finest element would give place to the old ideal with which Paul had to reckon that left to women no choice except as between a virtuous, but ignorant, domestic drudge, and a cultured courtesan. Is there a rational human being who has ever gotten far enough back in the barn-yard of common sense to be out of sight of the beaten paths of tradition and prejudice, who can believe for one moment that such is God's program for Christian womanhood today? It does not seem possible. And yet this is just what a literal interpretation of the Corinthian command, and a rigid application of it to womanhood today would force upon society. As utterly opposed to this ecclesiastical reactionary attitude, we may confidently hold that it is entirely in line with the spirit of Christ and the teachings of the New Testament that women shall have, in every department of Christian work and church life, full scope for all their powers, and that every barrier in the way of their development shall be removed.

And this may be judged, not only from the New Testament teachings, but as well from the gracious favor God 
has bestowed upon the public activities of consecrated women. Among the Quakers, Methodists and Baptists in other sections of the country, they have been signally used for the salvation of men and the inspiration of the church. In the Salvation Army, the Temperance Unions, and other kindred organizations, devout women have labored with an unusual degree of success. Has not Maud Ballington Booth, with other of the Booth women, been as wonderfully used of God as any man or family of men in this country or England? Men and women have been converted, instructed and inspired through the teaching of these godly women. And do not these and other like providences give unmistakable evidence that he who sets bounds to the use that God may make of women, holds an attitude which no reverent disciple of the Holy Spirit should dare assume?

Let it be once and for all accepted that there is no sex in the gifts of God. If a woman can sing, let her sing. If she can paint, let her paint. If she can write, let her write. If, like the woman at the well, she has had a vital experience with Christ, let her go out and tell it. If she has had a vision like the women at the sepulchre, let her be quick to give its inspiration and comfort to all who will receive them. If she has the lips of inspired eloquence, as did the anointed women of the day of Pentecost, let her speak. "There is nothing in the word of God, nothing in the church of Christ, nothing in the best interest of society that should hinder her from the exercise of her gifts." On the contrary, there is much to encourage and inspire her to use all her gifts and graces to crown Christ-to whom she owes so much in the redemption and exaltation of her womanhood-Lord of all. 